\title{
PENGARUH PENGGUNAAN MEDIA DIGITAL DAN KELAS LITERASI SECARA BERSAMA-SAMA TERHADAP HASIL BELAJAR SISWA
}

\author{
Aspari \\ Dosen Universitas Bina Sarana Informatika Kampus Kota Bogor \\ Jalan Merdeka No. 71, Ciwaringin, Bogor \\ Sur-el: aspari.spa@bsi.ac.id
}

\begin{abstract}
The goal of this research was to get data about the use of digital media and Class of Literation in together to achievement of student's learning at Anugerah Abadi Junior High School in Pamulang Tangerang Selatan. This research used method with correlation and regration analysis. The data about the use of digital media and Class of Literation in together to achievement of student's learning could be got over questioner by resercher with measuring something that has connection to: (1) there are effects of the use of digital media signficantly and Class of Literation in together to achievement of student's learning, (2) There are effects of the use of digital media significantly to achievement of student's learning, and (3) There are effects of Class of Literation to students learning achievment significantly. It tells us that there are possitive effects and significant to the use of digital media and Class of Literation in together to achievement of student's learning.
\end{abstract}

Keywords: Class Literation, the use of digital media, learning achievment.

\begin{abstract}
Abstrak: Tujuan dari peneitian ini adalah untuk mendatpakan data tentang penggunaan media digital dan kelas literasi secara bersama-sama terhadap hasil belajar siswa di SMP Anugerah Abadi Pamulang Tangerang Selatan. Data tentang penggunaan media digital dan kelas literasi secara bersama-sama terhadap hasil belajar siswa didapatkan melalui kuisioner oleh peneliti dengan mengukur sesuatu yang mempunyai hubungan bahwa: (1) Terdapat pengaruh yang signifikan penggunaan media digital dan kelas literasi secara bersama-sama terhadap hasil belajar siswa, (2) Terdapat pengaruh yang signifikan penggunaan media digital terhadap hasil belajar siswa, (3) Terdapat pengaruh yang signifikan kelas literasi terhadap hasil belajar siswa. Hal ini berarti terdapat dampak positif dan signifikan terhadap penggunaan media digital dan kelas literasi secara bersama-sama pada hasil belajar siswa.
\end{abstract}

Kata Kunci: Kelas Lliterasi, Penggunaan Media Digital, Hasil Belajar.

\section{PENDAHULULAN}

Undang-Undang Republik Indonesia nomor 20 tahun 2003 tentang Sistem Pendidikan Nasional Pasal 1 ayat 1 menyatakan bahwa, "Pendidikan adalah usaha sadar dan terencana untuk mewujudkan suasana belajar dan proses pembelajaran agar peserta didik secara aktif mengembangkan potensi dirinya untuk memiliki kekuatan spiritual keagamaan, pengendalian diri, kepribadian, kecerdasan, akhlak mulia serta keterampilan yang diperlukan dirinya, masyarakat, bangsa dan Negara".

Di era digital, teknologi dan informasi berkembang begitu cepatnya. Demikian pula perkembangan masyarakat dunia, dinamis bergerak maju begitu pesatnya. Kondisi ini menuntut agar pendidikan tidak ketinggalan zaman. Pendidikan harus mampu menjawab permasalahan dan tantangan zaman. 
Peningkatan kualitas manusia Indonesia dihasilkan melalui penyelenggaraan pendidikan yang bermutu (Undang-Undang Guru dan Dosen, 2006, p.2).

Pendidikan pada hakekatnya adalah usaha orang dewasa secara sadar untuk membimbing dan mengembangkan kepribadian serta kemampuan dasar / awal anak didik, baik dalam bentuk pendididkan formal dan formal.

Kualitas pendidikan tidak terlepas dari kualitas pembelajaran. Pendidikan memiliki beberapa permasalahan yang berintikan pada proses pembelajaran. Proses pembelajaran yang dilakukan bertujuan untuk kematangan belajar siswa yang bermuara pada peningkatan prestasi seperti yang diharapkan. Pembelajaran di sekolah merupakan proses interaksi antara guru, siswa, kurikulum, sarana pembelajaran termasuk media pembelajaran dan komponen lain yang berpengaruh pada proses pembelajaran untuk mencapai tujuan pembelajaran yang diharapkan, diantaranya proses managemen pendidikan.

Seiring dengan perkembangan ilmu pengetahuan dan teknologi yang terus berkembang pesat sekarang ini, akan membawa dampak kemajuan diberbagai bidang kehidupan. Agar dapat mengikuti dan meningkatkan perkembangan ilmu pengetahuan dan teknologi tersebut diperlukan sumber daya manusia yang berkualitas. Salah satunya usaha menciptakan sumber daya manusia yang berkualitas adalah melalui pendidikan.
Sebagai salah satu lembaga yang menyelenggarakan pendidikan secara formal, sekolah memiliki peranan yang sangat penting dalam mewujudkan tujuan pendidikan nasional melalui proses belajar mengajar. Pendidikan mempunyai fungsi yang harus diperhatikan, seperti dapat dilihat pada UU No.20 tahun 2003 menyebutkan bahwa :

"Pendidikan nasional berfungsi mengembangkan kemampuan dan membentuk watak serta peradaban bangsa yang bermanfaat dalam rangka mencerdaskan kehidupan bangsa, bertujuan untuk perkembangannya potensi peserta didik agar menjadi manusia yang beriman dan bertaqwa pada Tuhan Yang Maha Esa, berakhak mulia, sehat ilmu, cakap, kreatif, mandiri, dan menjadi warga yang demokratis dan tanggung jawab."

Guru adalah faktor yang berperan penting dalam pendidikan, menurut Cece Wijaya, dan A. Tabrani Rusyan (1992, p.10) "Guru adalah faktor yang paling penting dalam pendidikan formal, karena guru terlibat langsung dalam pembentukan dan pengembangan intelektual dan kepribadian siswa". Oleh karena itu, guru sering dijadikan tokoh teladan bahkan dijadikan tokoh identitas diri, dengan demikian guru harus memilki perilaku, keterampilan dan kemampuan yang memadai untuk melaksanakan tugasnya dengan baik. Untuk itu, guru harus menguasai berbagai hal sebagai keterampilan yang dimiliki.

Guru harus memahami dan mengahayati para siswa yang dibinanya, karena wujud siswa pada setiap saat tidak akan sama, ini disebabkan oleh perkembangan ilmu 
pengetahuan dan teknologi. Berhasil tidaknya suatu proses belajar mengajar dapat diketahui dari hasil belajar mengajar tersebut yang pada umumnya dikaitkan dengan tinggi rendahnya nilai yang dicapai siswa, daya serap siswa serta prestasi siswa yang berupa nilai hasil raport.

Sudah tidak dapat dipungkiri lagi bahwa penggunaan media digital tidak dapat dihindari lagi di hampir setiap sendi kehidupan manusia. Lembaga Pendidikan atau Guru yang teliti dan cermat membaca situasi seperti ini maka pasti akan memanfaatkan media digital sebagai salah satu media yang digunakan dalam proses pembelajaran. Seperti yang juga sudah dilakukan oleh pemerintah dengan pelaksanaan ujian berbasis komputer (UNBK) untuk siswa tingkat akhir.

Seirring dengan perkembangan ini, pemerintah juga tidak tinggal diam, terbukti dengan adanya sumber-sumber belajar yang disediakn secara online atau digital dalam benuk e-book yang dapat diakses dengan mudah oleh seluruh siswa dan guru di seluruh Indonesia. Disisi lain lembaga pendidikan juga harus jeli melihat hal ini dengan cara memanfaatkan apa yang telah disediakan oleh pemerintah.

Kesusksesan siswa yang notabene dilihat dari hasil belajar mereka yang berupa nilai rapor dan atau prestasi lainnya, tidak dapat dipungkri bahwa adalah faktor banyak membaca sumber belajar. Maka dari itu adanya kelas literasi perlu untuk diadakan disetiap lembaga pendidikan. Kelas literasi yang dimaksud adalah kelas dimana hanya diisi dengan membaca sumber belajar yang bersumber dari perbagai sumber, baik berupa e-book, buku, video, dan sebagainya. Yang semuanya itu bertujuan untuk memberikan waktu khusus kepada siswa agar bisa lebih fokus dalam membaca.

Membaca adalah suatu pekerjaan yang sangat banyak manfaatnya akan tetapi tidak semua orang memiliki minat baca yang tinggi, sebab bagi sebagian orang membaca itu membosankan. Menurut Widyamartaya (1992, p.140-141), membaca dapat membuka cakrwala kehidupan, menyaksikan dunia laindunia pikiran dan renungan, dan merubah pembaca menjadi mempesoana dan terasa nikmat tutur katanya.

Sedangakan Farida Rahim (2008, p.2) mengungkapkan bahwa Kegiatan membaca meliputi 3 keterampilan dasar yaitu recording, decoding, dan meaning. Recording merujuk pada kata-kata dan kalimat, kemudian mengasosiakannya dengan bunyi-bunyinya sesuai dengan sistem tulisan yang digunakan. Proses decoding merujuk pada proses penerjemahan rangkaian grafis ke dalam katakata. Sedangkan meaning merupakan proses memahami makna yang berlangsung dari tingkat pemahaman, pemahaman interpretatif, kreatif, dan evaluatif. Proses recording dan decoding berlangsung pada siswa kelas awal, sedangkan meaning lebih ditekankan pada kelas tinggi.

Dengan demikian prestasi belajar siswa ditentukan oleh interaksi berbagai faktor. 
Peranan faktor penentu itu tidak selalu sama dan tetap. Besarnya kontribusi salah satu faktor akan ditentukan oleh kehadiran faktor lain dan sangat bersifat situsional, yaitu tidak dapat diprediksi dengan cermat akibat keterlibatan faktor lain yang sangat variatif. Penelitian ini dilakukan untuk mengetahui sejauh mana pengaruh penggunaan media digital dan kelas literasi terhadap hasil belajar siswa.

Berdasarkan uraian tersebut diatas, maka tujuan penellitian ini adalah sebagai berikut:

1. Untuk mengetahui apakah faktor penggunaan media digital dan kelas literasi secara bersama-sama berpengaruh signifikan terhadap hasil belajar siswa-siswi sekolah menengah pertama Augerah Abadi di Pamulang Tangerang Selatan Banten.

2. Untuk mengetahui apakah faktor Penggunaan Media Digital berpengaruh signifikan terhadap hasl belajar siswa-siswi sekolah menengah pertama Anugerah Abdi di Pamulang Tangerang Selatan Banten.

3. Untuk mengetahui apakah faktor kelas literasi berpengaruh signifikan terhadap hasil belajar siswa-siswi sekolah menengah pertama Anugerah Abadi di Pamulang Tangerang Selatan Banten.

\section{METODOLOGI PENELITIAN}

Penelitian ini dilaksanakan di Sekolah Menengah Pertama (SMP) Anugerah Abadi di Pamulang wilayah Kota Tangerang Selatan.
Dan adapun waktu penelitiannya adalah pada semester pertama tahun pelajaran 2019/2020 selama 6 bulan yaitu pada bulan Juli sampai dengan Desember 2019.

Tahap- tahap pelaksanaan penelitian yang dilakukan adalah (1) Pendekatan dengan instansi terkait untuk mengajukan permohonan ijin penelitian yaitu pada kepala sekolah. (2) Mempersiapkan instrumen sekaligus uji instrumen penelitian (angket) (3) Koordinasi dengan kepala skolah dan guru di sekolah tempat mengambil data. (4) Pelaksanaan, 60 sampling berupa angket yang disebarkan dan pengumpulan data lapangan (5) Pengolahan data dan penyusunan pelaporan penelitian.

Adapun jenis penelitian yang digunakan adalah penelitian kuantitatif dengan metode Eksperimental (Experimental Recearch) untuk menguji secara langsung pengaruh suatu variabel terhadap variabel yang lain dan menguji hipotesis hubungan sebab akibat. Kuantitatif karena untuk pengujian hipotesis menuju sebuah kesimpulan dilakukan dengan mengumpulkan, mendeskripsikan dan menganalisis data yang menekankan pada data-data numerik. Eksperimental karena penelitian ini memberi perlakuan (treatment) terhadap kelompok eksperimen dan pengontrolan terhadap variabel-variabel. Jadi pernelitian Eksperimental bersifat validation atau menguji (Syaodih: 2005, p.57) yaitu menguji pengaruh satu variabel atau lebih terhadap variabel yang lain. Dalam penelitian ini menguji pengaruh motivasi dan gaya 
belajar terhadap hasil belajar siswa sebagai variabel terikat.

Penelitian eksperimen memiliki dua kekuatan yang keberadaanya sering digunakan sebagai rekomendasi penelitian. Pertama, ekseperimen umumnya dianggap sebagai metode yang paling tepat untuk menguji hipotesis. Metode ini mengungkap hubungan antara variabel, mengajukan hipotesis dan selanjutnya melakukan pengujian. Kedua, kemampuan metode ini dalam penggunaannya sebagai prediktif terhadap permasalahan. Sebagaimana karakteristiknya, ekperimen direncanakan dan dilaksanakan untuk mengumpulkan data, yang digunakan untuk menguji hipotesis. Penelitian dengan menggunakan metode eksperimen dengan sengaja dan sistematis mengadakan perlakuan variabel, kemudian mengamati konsekuensi perlakuan tersebut. Hipotesis merupakan suatu jawaban yang bersifat sementara terhadap permasalahan penelitian, sampai terbukti melalui data yang terkumpul (Arikunto, 2006, p.71).

\section{HASIL}

Dari hasil analisis data yang dilakukan dalam penelitian ini, maka diperoleh hasil sebagai berikut:

(Untuk variabel hasil belajar siswa (Y), Penggunaan Media Digital $\left(\mathrm{X}_{1}\right)$, dan Kelas Literasi $\left.\left(\mathrm{X}_{2}\right)\right)$.

\subsection{Deskripsi Data}

\section{Data Hasil Belajar siswa (Y)}

Data hasil belajar siswa diperoleh dari nilai tes yang diberikan kepada siswa yang menjadi sampel penelitian sebanyak 60 siswa. Nilai yang di peroleh adalah terendah 50, tertinggi 95, rata-rata sebesar 80,5, median sebesar 80, modus sebesar 90 dan simpangan baku sebesar 12,306.

Tabel 4.1. Deskripsi data Penelitian hasil belajar siswa

\begin{tabular}{|c|c|c|}
\hline \multicolumn{3}{|c|}{ Statistics } \\
\hline \multicolumn{3}{|c|}{ Hasil Belajar siswa } \\
\hline \multirow[t]{2}{*}{$\mathrm{N}$} & \begin{tabular}{|l|} 
Valid \\
\end{tabular} & 60 \\
\hline & Missing & $\mathbf{0}$ \\
\hline \multicolumn{2}{|c|}{ Mean } & 80,50 \\
\hline \multicolumn{2}{|c|}{ Median } & 80,00 \\
\hline \multicolumn{2}{|c|}{ Mode } & 90 \\
\hline \multicolumn{2}{|c|}{ Std. Deviation } & 12,306 \\
\hline \multicolumn{2}{|c|}{ Minimum } & 50 \\
\hline \multicolumn{2}{|c|}{ Maximum } & 95 \\
\hline
\end{tabular}

Bila dilihat dari hasil perhitungan di atas, maka bisa dikatakan bahwa hasil belajar siswa SMP Anugerah Abdi di Pamulang Kota Tangerang Selatan tergolong baik. Hal ini di indikasikan dengan perolehan skor rata-rata sebesar 80,5 .

Untuk memperjelas data di atas, digambarkan dalam histogram sebagai berikut:

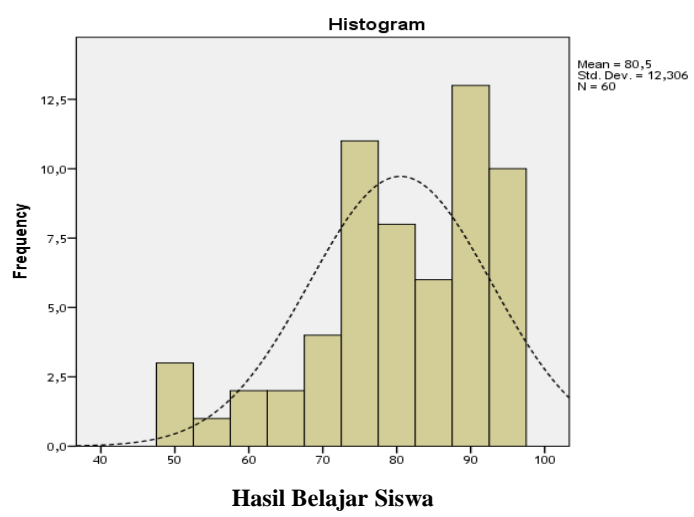


Gambar 4.1. Histogram Poligon Variabel hasil belajar siswa

Dari histogram dan polygon frekuensi di atas dapat disimpulkan bahwa hasil (prestasi) belajar siswa SMP Anugerah Abadi di Pamulang Kota Tangerang Selatan memiliki sebaran yang normal.

\section{Data Penggunaan Media Digital (X1)}

Data penggunaan media digital diperoleh dari skor angket yang diberikan kepada siswa yang menjadi sampel penelitian sebanyak 60 siswa dihasilkan skor terendah 68 , tertinggi 98 , rerata sebesar 85,23, median 85, modus sebesar 83, dan simpangan baku sebesar 6,801.

Tabel 4.2. Deskripsi data Penelitian Penggunaan Media Digital

\begin{tabular}{|c|c|c|}
\hline \multicolumn{3}{|c|}{$\begin{array}{r}\text { Statistics } \\
\end{array}$} \\
\hline \multicolumn{3}{|c|}{ Penggunaan Media Digital } \\
\hline \multirow[t]{2}{*}{$\mathrm{N}$} & Valid & 60 \\
\hline & Missing & $\mathbf{0}$ \\
\hline \multicolumn{2}{|c|}{ Mean } & 85,23 \\
\hline \multicolumn{2}{|c|}{ Median } & 85,00 \\
\hline \multicolumn{2}{|c|}{ Mode } & 83 \\
\hline \multicolumn{2}{|c|}{ Std. Deviation } & 6,801 \\
\hline \multicolumn{2}{|c|}{ Minimum } & 68 \\
\hline \multicolumn{2}{|c|}{ Maximum } & 98 \\
\hline
\end{tabular}

Dari hasil perhitungan di atas, maka bisa dikatakan bahwa Penggunaan Media Digital siswa SMP Anujgerah Abadi di Pamulang Kota Tangerang Selatan baik. Hal ini di indikasikan dengan perolehan skor rerata sebesar 85,23 lebih tinggi dari skor mediannya.

Untuk memperjelas data di atas, digambarkan dalam histogram sebagai berikut:

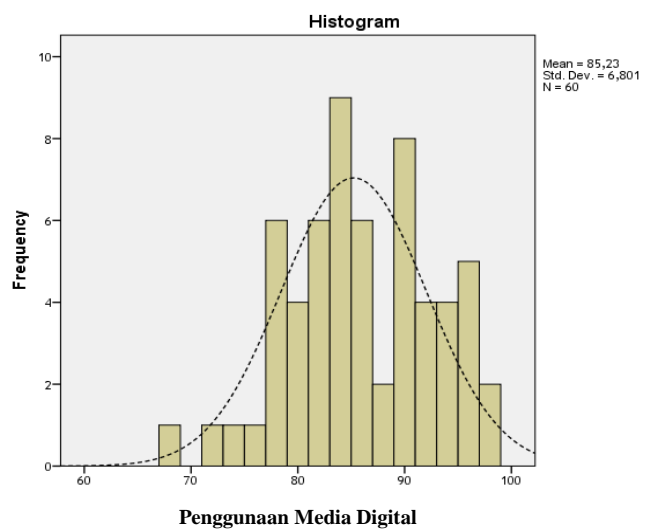

\section{Gambar 4.2. Histogram Poligon Variabel Penggunaan Media DIgital}

Dari histogram dan polygon frekuensi di atas dapat disimpulkan bahwa Penggunaan Media Digital SMP Anugerah Abadi di Pamulang Kota Tangerang Selatan. memiliki sebaran yang normal.

\section{Data Kelas Literasi (X2)}

Data Kelas literasi diperoleh dari nilai tes yang diberikan kepada siswa yang menjadi sampel penelitian sebanyak 60 siswa dihasilkan nilai terendah 53, tertinggi 102 , rerata sebesar 84,65, median sebesar 86, modus sebesar 83 dan simpangan baku sebesar 8,266 .

Tabel 4.3. Deskripsi data Penelitian Kelas Literasi

\begin{tabular}{|c|c|c|}
\hline \multicolumn{3}{|c|}{$\begin{array}{r}\text { Statistics } \\
\end{array}$} \\
\hline \multicolumn{3}{|c|}{ Kelas Literasi } \\
\hline \multirow[t]{2}{*}{$\mathrm{N}$} & Valid & 60 \\
\hline & Missing & $\mathbf{0}$ \\
\hline \multicolumn{2}{|c|}{ Mean } & 84,65 \\
\hline \multicolumn{2}{|c|}{ Median } & 86,00 \\
\hline \multicolumn{2}{|c|}{ Mode } & 83 \\
\hline \multicolumn{2}{|c|}{ Std. Deviation } & 8,266 \\
\hline \multicolumn{2}{|c|}{ Minimum } & 53 \\
\hline \multicolumn{2}{|c|}{ Maximum } & 102 \\
\hline
\end{tabular}


Dari hasil perhitungan diatas, maka bisa dikatakan bahwa Kelas Literasi SMP Anugerah Abadi di Pamulang Kota Tangerang Selatan cukup baik. Hal ini di indikasikan dengan perolehan nilai rerata 84,65 mendekati nilai mediannya.

Untuk memperjelas data di atas, digambarkan dalam histogram sebagai berikut:

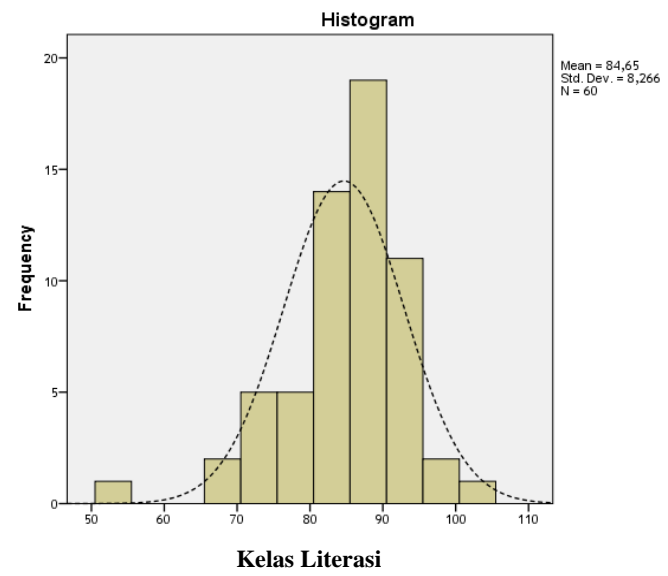

Gambar 4.3. Histogram Poligon Variabel Kelas Literasi

Dari histogram dan polygon frekuensi di atas dapat disimpulkan bahwa kelas literasi SMP Anugerah Abadi di Pamulang Kota Tangerang Selatan memiliki sebaran yang normal.

\subsection{Uji Persyaratan Analisis Regresi}

\section{Uji Asumsi Klasik}

a. Uji Normalitas Data

Persyaratan regresi yang baik jika data penelitian mengikuti distribusi normal.

Tabel 4.4. Uji Normalitas Data

\begin{tabular}{|l|l|r|l|r|}
\hline \multicolumn{5}{|c|}{ One-Sample Kolmogorov-Smirnov Test } \\
\hline \multicolumn{2}{|c|}{} & $\begin{array}{l}\text { Hasil } \\
\text { Belajar siswa }\end{array}$ & $\begin{array}{l}\text { Penggun } \\
\text { aan } \\
\text { Media } \\
\text { Digital }\end{array}$ & $\begin{array}{l}\text { Kelas } \\
\text { Literasi }\end{array}$ \\
\hline N & 60 & $\mathbf{6 0}$ & $\mathbf{6 0}$ \\
\hline Normal & Mean & $\mathbf{8 0 , 5 0}$ & $\mathbf{8 5 , 2 3}$ & $\mathbf{8 4 , 6 5}$ \\
\hline
\end{tabular}

\begin{tabular}{|c|c|c|c|c|}
\hline $\begin{array}{l}\text { Paramet } \\
\text { ers }^{\mathrm{a}, \mathrm{b}}\end{array}$ & $\begin{array}{l}\text { Std. } \\
\text { Deviation }\end{array}$ & 12,306 & 6,801 & 8,266 \\
\hline \multirow{3}{*}{$\begin{array}{l}\text { Most } \\
\text { Extreme } \\
\text { Differen } \\
\text { ces } \\
\end{array}$} & Absolute & ,163 & ,112 & 138 \\
\hline & Positive & ,119 & ,112 & ,079 \\
\hline & Negative &,- 163 &,- 093 &,- 138 \\
\hline \multicolumn{2}{|c|}{ Kolmogorov-Smirnov Z } & 1,265 & ,868 & 1,066 \\
\hline \multicolumn{2}{|c|}{ Asymp. Sig. (2-tailed) } &, 082 & ,439 & ,206 \\
\hline \multicolumn{5}{|c|}{ a. Test distribution is Normal. } \\
\hline \multicolumn{5}{|c|}{ b. Calculated from data. } \\
\hline
\end{tabular}

Dari tabel di atas menunjukkan bawha uji hipotesis yang menyatakan distribusi data pada analisis regresi ini mengikuti distribusi normal. Hal ini ditunjukkan dengan semua nilai Asymp. Sig > 0,05. Hal ini berarti semua data berdistribusi normal

\section{b. Uji Multikolinearitas}

Uji multikolinieritas bertujuan untuk menguji apakah model regresi ditemukan adanya korelasi yang sempurna antarvariabel bebas (independent). Model regresi yang baik seharusnya tidak terjadi korelasi yang sempurna diantara variabel bebas. Salah satu cara untuk untuk mendeteksi adanya multikolinieritas adalah dengan melihat tolerance atau varian inflation factor (VIF). Apabila tolerance $<0,1$ atau nilai VIF $>10$ maka terjadi multikolinearitas.

Tabel 4.5. Uji Multikolinearitas

\begin{tabular}{|c|l|r|r|}
\hline \multicolumn{4}{|c|}{ Coefficients $^{\mathbf{a}}$} \\
\hline \multirow{2}{*}{ Model } & \multicolumn{2}{l|}{ Collinearity Statistics } \\
\cline { 2 - 4 } & Tolerance & VIF \\
\hline \multirow{3}{*}{1} & (Constant) & & \\
\cline { 2 - 4 } & $\begin{array}{l}\text { Penggunaan } \\
\text { Media Digital }\end{array}$ & $\mathbf{, 7 5 2}$ & $\mathbf{1 , 3 3 0}$ \\
\cline { 2 - 4 } & Kelas Literasi & $\mathbf{, 7 5 2}$ & $\mathbf{1 , 3 3 0}$ \\
\hline
\end{tabular}

Hasil uji multikolininearitas pada tabel di atas diketahui bahwa hasil Tolerance 0,752 > 0,1 atau varian inflation factor $(\mathrm{VIF})=1,330$ $<10$. Sehingga dapat dinyatakan bahwa tidak ada multikolinearitas antara penggunaan media 
digital dan kelas literasi pada analisis regresi ganda ini.

\section{c. Uji Heteroskedastisitas}

Pengertian heteroskedastisitas adalah apabila kesalahan atau residual yang diamati tidak memiliki varian yang konstan. Kondisi heteroskedastisitas sering terjadi pada data cross section, atau data yang diambil dari beberapa responden pada suatu waktu tertentu.

Salah satu metode untuk mendeteksi adanya heteroskedastisitas adalah dengan membuat scatter-plot antara standardized Residual (ZRESID) dan Standardized Predicted Value (Y topi). Pada gambar dibawah ini menunjukkan tidak ada perubahan e sepanjang Y topi, maka dinyatakan tidak ada heteroskedastisitas pada galat (error/residual ) tersebut.

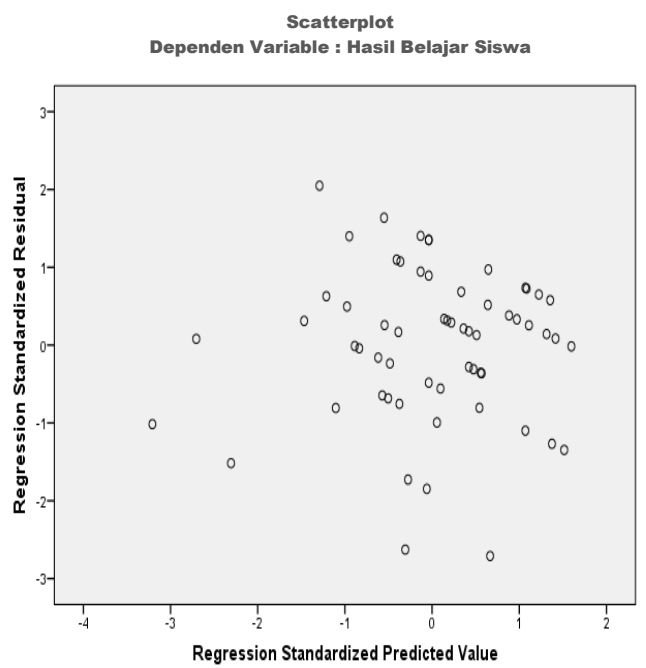

Gambar 4.3. Scatterplot Uji Heteroskedastisitas

Dari gambar di atas menunjukkan bahwa titik-titik menyebar secara acak dan tidak membentuk pola tertentu yang jelas, serta tersebar di atas maupun di bawah angka 0 pada sumbu Y. Hal ini menunjukkan bahwa tidak terjadi heteroskedastisitas pada model regresi tersebut, sehingga dapat dipakai untuk memprediksi variable hasil Belajar siswa berdasarkan penggunaan media digital dan kelas literasi.

\section{d. Uji Normalitas Galat}

Persyaratan regresi yang baik jika data penelitian mengikuti distribusi normal.

Tabel 4.6. Uji Normalitas Galat

\begin{tabular}{|l|l|r|}
\hline \multicolumn{2}{|c|}{ One-Sample Kolmogorov-Smirnov Test } \\
\hline \multicolumn{2}{|c|}{} & $\begin{array}{l}\text { Unstandardized } \\
\text { Residual }\end{array}$ \\
\hline $\mathrm{N}$ & $\mathbf{6 0}$ \\
\hline \multirow{2}{|l|}{$\begin{array}{l}\text { Normal } \\
\text { Parameters }\end{array}$} & Mean & $\mathbf{0 E - 7}$ \\
\cline { 2 - 3 } & $\begin{array}{l}\text { Std. } \\
\text { Deviation }\end{array}$ & $\mathbf{1 0 , 7 1 2 7 0 7 4 6}$ \\
\hline $\begin{array}{l}\text { Most Extreme } \\
\text { Differences }\end{array}$ & Absolute & $\mathbf{1 0 0}$ \\
\cline { 2 - 3 } & Positive & $\mathbf{, 0 4 4}$ \\
\cline { 2 - 3 } & Negative & $\mathbf{- , 1 0 0}$ \\
\hline \multicolumn{2}{|l|}{ Kolmogorov-Smirnov Z } & $\mathbf{7 7 7}$ \\
\hline Asymp. Sig. (2-tailed) & $\mathbf{5 8 3}$ \\
\hline \multicolumn{2}{|l}{ a. Test distribution is Normal. } \\
\hline \multicolumn{2}{|l}{ b. Calculated from data. } \\
\hline
\end{tabular}

Dari tabel di atas menunjukkan bawha uji hipotesis yang menyatakan distribusi residual pada analisis regresi ini mengikuti distribusi normal. Hal ini ditunjukkan dengan nilai $\mathrm{Z}=$ 0,777 dan Sig. $=0,583>0,05$. Hal ini berarti asumsi atau persyaratan analisis regresi terpenuhi.

\section{Uji Linearitas}

Uji lineritas dilakukan untuk menentukan teknik dalam analisis regresi apakah variabel bebas $\left(\mathrm{X}_{1}\right.$ dan $\left.\mathrm{X}_{2}\right)$ dan variabel terikat $(\mathrm{Y})$ terbentuk linear. Uji linearitas ini menggunakan perhitungan SPSS 20.0 


\section{a. Linaeritas Regresi pengaruh variable} $\mathbf{X}_{1}$ atas $\mathbf{Y}$

Hasil uji linearitas regresi antara penggunaan media digital dengan hasil belajar, perhitungan SPSS 20.0 sebagai berikut:

Tabel 4.7. Hasil Pengujian Linearitas Regresi Variabel Y atas $X_{1}$

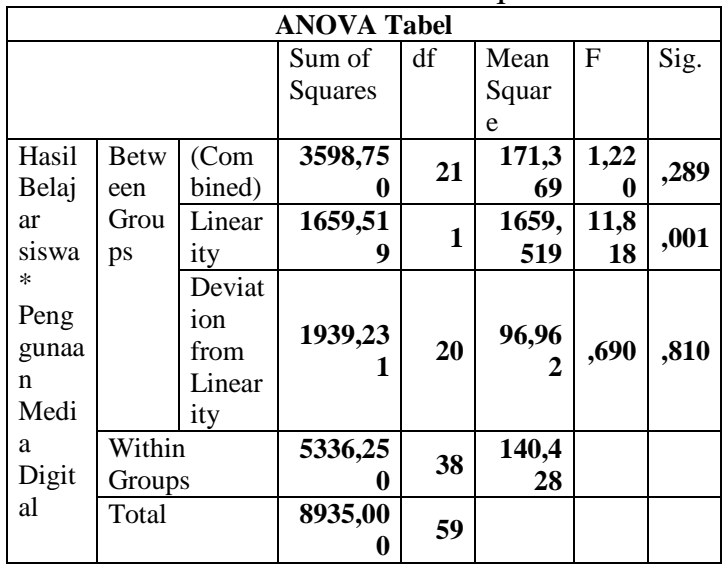

Berdasarkan hasil perhiungan di atas diperoleh hasil perhitungan Deviation from Linearity dengan Fo $=0,690$ dan Sig. $=0,810$ $>0,05$. Hal ini memiliki pengertian bahwa variabel penggunaan media digital dengan hasil belajar siswa mempunyai mempunyai hubungan yang linear.

\section{b. Linaeritas Regresi pengaruh variable \\ $\mathbf{X}_{2}$ atas $\mathbf{Y}$}

Hasil uji linearitas regresi antara kelas literasi dengan hasil belajar siswa, perhitungan SPSS 20.0 sebagai berikut:

Tabel 4.8. Hasil Pengujian Linearitas Regresi Variabel $Y$ atas $X_{2}$

\begin{tabular}{|c|c|c|c|c|c|c|c|}
\hline \multicolumn{8}{|c|}{ ANOVA Tabel } \\
\hline & & & $\begin{array}{l}\text { Sum of } \\
\text { Squares }\end{array}$ & df & $\begin{array}{l}\text { Mean } \\
\text { Squar } \\
\mathrm{e}\end{array}$ & $\mathrm{F}$ & Sig. \\
\hline \multirow{2}{*}{$\begin{array}{l}\text { Hasil } \\
\text { Belaja } \\
\mathrm{r} \\
\text { Siswa }\end{array}$} & \multirow{2}{*}{$\begin{array}{l}\text { Bet } \\
\text { wee } \\
n \\
\text { Gro }\end{array}$} & $\begin{array}{l}\text { (Com } \\
\text { bined) }\end{array}$ & $\begin{array}{r}3715,89 \\
3\end{array}$ & 25 & $\begin{array}{r}148,6 \\
36\end{array}$ & ,968 &, 527 \\
\hline & & $\begin{array}{l}\text { Linear } \\
\text { ity }\end{array}$ & $\begin{array}{r}1582,02 \\
0\end{array}$ & 1 & $\begin{array}{r}1582, \\
020\end{array}$ & $\begin{array}{r}10,30 \\
6\end{array}$ & ,003 \\
\hline
\end{tabular}

\begin{tabular}{|c|c|c|c|c|c|c|c|}
\hline \multirow[t]{3}{*}{$\begin{array}{l}* \\
\text { Kelas } \\
\text { Litera } \\
\text { si }\end{array}$} & ups & $\begin{array}{l}\text { Deviat } \\
\text { ion } \\
\text { from } \\
\text { Linear } \\
\text { ity }\end{array}$ & $\begin{array}{r}2133,87 \\
3\end{array}$ & 24 & $\begin{array}{r}88,91 \\
1\end{array}$ & ,579 & 917, \\
\hline & \multicolumn{2}{|c|}{$\begin{array}{l}\text { Within } \\
\text { Groups }\end{array}$} & $\begin{array}{r}5219,10 \\
7\end{array}$ & 34 & $\begin{array}{r}153,5 \\
03\end{array}$ & & \\
\hline & \multicolumn{2}{|c|}{ Total } & $\begin{array}{r}8935,00 \\
0\end{array}$ & 59 & & & \\
\hline
\end{tabular}

Berdasarkan hasil perhiungan di atas diperoleh hasil Deviation from Linearity dengan Fo $=0,579$ dan Sig. $=0,917>0,05$. Hal ini memili pengertian bahwa variabel literasi kelas dengan hasil belajar siswa mempunyai mempunyai hubungan yang linear.

\subsection{Pengujian Hipotesis}

Pengajuan hipotesis dilakukan sesuai dengan ketentuan yang telah dijelaskan dalam Bab III. Hasil perhitungan dan pengujian bisa dilihat pada tabel di bawah ini:

Tabel 4.9. Hasil Perhitungan Pengujian Koefisien Korelasi

Ganda Variabel $X_{1}$ dan $X_{2}$ terhadap $Y$

\begin{tabular}{|l|l|l|l|l|}
\hline \multicolumn{5}{|c|}{ Model Summary } \\
\hline Model & R & $\begin{array}{l}\text { R } \\
\text { Square }\end{array}$ & $\begin{array}{l}\text { Adjusted R } \\
\text { Square }\end{array}$ & $\begin{array}{l}\text { Std. } \\
\text { Error } \\
\text { of the } \\
\text { Estima } \\
\text { te }\end{array}$ \\
\hline 1 & & $\mathbf{4 9 2}^{\text {a }}$ & $\mathbf{, 2 4 2}$ & \multicolumn{2}{|c|}{$\mathbf{1 6}$} & $\mathbf{1 0 , 8 9 9}$ \\
\hline $\begin{array}{l}\text { a. Predictors: (Constant), Kelas Literasi, } \\
\text { Penggunaan Media Digital }\end{array}$ \\
\hline
\end{tabular}

Tabel 4.10. Hasil Perhitungan Pengujian Signifikansi Koefisien Regresi Variabel $X_{1}$ dan $\mathrm{X}_{2}$ terhadap $\mathrm{Y}$

\begin{tabular}{|c|c|c|c|c|c|c|}
\hline \multicolumn{7}{|c|}{ ANOVA $^{a}$} \\
\hline \multicolumn{2}{|c|}{ Model } & Sum of & Df & $\begin{array}{l}\text { Mean } \\
\text { Saura }\end{array}$ & $\mathrm{F}$ & Sig. \\
\hline \multirow[t]{3}{*}{1} & $\begin{array}{l}\text { Regre } \\
\text { ssion }\end{array}$ & $\begin{array}{r}2164,0 \\
36\end{array}$ & 2 & 1082,018 & 9,109 &, $000^{b}$ \\
\hline & $\begin{array}{l}\text { Resid } \\
\text { ual }\end{array}$ & $\begin{array}{r}6770,9 \\
64 \\
\end{array}$ & 57 & 118,789 & & \\
\hline & Total & $\begin{array}{r}8935,0 \\
00\end{array}$ & 59 & & & \\
\hline \multicolumn{7}{|c|}{ a. Dependent Variable: Hasil Belajar Siswa } \\
\hline \multicolumn{7}{|c|}{$\begin{array}{l}\text { b. Predictors: (Constant), Kelas Literasi, Penggunaan } \\
\text { Media Digital }\end{array}$} \\
\hline
\end{tabular}


Tabel 4.11. Hasil Perhitungan Persamaan Regresi Ganda Variabel $X_{1}$ dan $X_{2}$ terhadap $Y$

\begin{tabular}{|c|c|c|c|c|c|c|}
\hline & & & efficien & & & \\
\hline & & $\begin{array}{l}\text { Unstand } \\
\text { Coeffici }\end{array}$ & $\begin{array}{l}\text { ardized } \\
\text { ents }\end{array}$ & $\begin{array}{l}\text { Standa } \\
\text { rdized }\end{array}$ & $\mathrm{T}$ & Sig. \\
\hline & & B & $\begin{array}{l}\text { Std. } \\
\text { Error }\end{array}$ & Beta & & \\
\hline 1 & $\begin{array}{l}\text { (Constan } \\
\text { t) }\end{array}$ &, 558 & $\begin{array}{r}18,99 \\
9\end{array}$ & & ,029 & 977 \\
\hline & $\begin{array}{l}\text { Penggun } \\
\text { aan } \\
\text { Media } \\
\text { Digital }\end{array}$ &, 533 & ,241 & 294 & 2,214 & ,031 \\
\hline & $\begin{array}{l}\text { Kelas } \\
\text { Literasi }\end{array}$ & ,408 & ,198 & ,274 & 2,061 & ,044 \\
\hline
\end{tabular}

1. Pengaruh Penggunaan Media Digital (X1) dan Kelas Literasi (X2) secara bersama-sama terhadap Hasil Belajar $\operatorname{Siswa}(\mathbf{Y})$

$$
\begin{aligned}
& \text { Hipotesis yang diuji: } \\
& \qquad \begin{array}{l}
H_{0}: \beta_{y 1}=\beta_{y 2}=0 \\
H_{1}: \beta_{y 1} \neq 0, \beta_{y 2} \neq 0
\end{array}
\end{aligned}
$$

\section{Artinya:}

$\mathrm{H}_{0} \quad$ : tidak terdapat pengaruh Penggunaan Media Digital dan Kelas Literasi secara bersama-sama terhadap hasil Belajar Siswa

$\mathrm{H}_{1}$ : terdapat pengaruh Penggunaan Media Digital dan Kelas Literasi secara bersama-sama terhadap hasil Belajar Siswa

Dari tabel 4.10. dapat dinyatakan bahwa terdapat pengaruh yang signifikan Penggunaan Media Digital dan Kelas Literasi secara bersama-sama terhadap hasil belajar siswa. Hal ini dibuktikan dengan perolehan nilai Fo = 9,109 dan Sig. 0,000 < 0,05

Sementara itu, persamaan garis regresi ganda dapat dinyatakan dengan $\hat{Y}=0,558+$ $0,533 \mathrm{X} 1+0,408 \mathrm{X} 2$. Hal ini memiliki pengertian bahwa variable penggunaan media digital dan kelas literasi memberikan kontribusi positif terhadap variable hasil belajar siswa. Dari tabel 4.9 juga dapat menjelaskan bahwa secara bersama-sama variable penggunaan media digital dan kelas literasi memberikan kontribusi sebesar 24,2 \% terhadap variable hasil belajar siswa.

\section{Pengaruh Penggunaan Media Digital $\left(\mathbf{X}_{1}\right)$ terhadap Hasil Belajar Siswa $(\mathbf{Y})$}

Hipotesis yang diuji:

$$
\begin{aligned}
& H_{0}: \beta_{y 1}=0 \\
& H_{1}: \beta_{y 1} \neq 0
\end{aligned}
$$

\section{Artinya:}

$\mathrm{H}_{0}$ : tidak terdapat pengaruh penggunanna media digital terhadap hasil belajar siswa

$\mathrm{H}_{1}$ : terdapat pengaruh penggunaan media digital terhadap hasil belajar siswa.

Dari tabel 4.11. dapat dinyatakan bahwa terdapat pengaruh yang signifikan penggunaan media digital terhadap hasil belajar siswa. Hal ini dibuktikan dengan perolehan nilai $t_{\text {hitung }}=$ 2,214 dan Sig. 0,031<0,05.

Adapun kontribusi variabel penggunaan media digital terhadap hasil belajar siswa dapat dinyatakan dengan rumus:

$\mathrm{KD}=$ Nilai $\beta_{x 1 y} \times$ Nilai Korelasi Pasialnya $\left(r_{x 1 y}\right) \times 100 \%$

$\mathrm{KD}=0,294 \times 0,431 \times 100 \%=12,67 \%$

Dari hasil perhitungan di atas dapat dinyatakan bahwa kontribusi pengguanaan media digital dalam meningkatkan hasil belajar siswa sebesar 12,67 \%. 


\section{Pengaruh Kelas Literasi (X2) terhadap Hasil Belajar Siswa (Y)}

Hipotesis yang diuji:

$$
\begin{aligned}
& H_{0}: \beta_{y 2}=0 \\
& H_{1}: \beta_{y 2} \neq 0
\end{aligned}
$$

Artinya:

$\mathrm{H}_{0}$ : tidak terdapat pengaruh kelas literasi terhadap hasil belajar siswa

$\mathrm{H}_{1} \quad$ : terdapat pengaruh kelas literasi terhadap hasil belajar siswa.

Dari tabel 4.11. dapat dinyatakan bahwa terdapat pengaruh yang signifikan kelas literasi terhadap haskil belajar siswa. Hal ini dibuktikan dengan perolehan nilai $t_{\text {hitung }}=$ 2,061 dan Sig. 0,044<0,05.

Adapun kontribusi variabel kelas terasi terhadap hasil belajar siswa dapat dinyatakan dengan rumus:

$\mathrm{KD}=$ Nilai $\beta_{x 2 y} \times$ Nilai Korelasi Pasialnya $\left(r_{x 2 y}\right) \times 100 \%$

$\mathrm{KD}=0,274 \times 0,421 \times 100 \%=11,53 \%$

Dari hasil perhitungan di atas dapat dinyatakan bahwa kontribusi kelas literasi dalam meningkatkan hasil belajar siswa sebesar $11,53 \%$.

\subsection{Pengaruh Penggunaan Media}

Digital (X1) dan Kelas Literasi (X2)

Secara Bersama-Sama Terhadap Hasil

\section{Belajar Siswa (Y)}

Hasil penelitian di atas menyimpulkan bahwa penggunaan media digital dan kelas literasi secara bersama-sama telah memberikan pengaruh positif terhadap peningkatan hasil belajar siswa di SMP Anugerah Abadi di Pamulang Kota Tangerang Selatan. Hal ini mengandung arti bahwa penggunaan media digital dan kelas literasi telah memberikan pengaruh yang signifikan terhadap peningkatan hasil belajar siswa di SMP Anugerah Abadi di Pamulang Kota Tangerang Selatan.

Hasil belajar siswa ditentukan antara lain oleh penggunaan media digital dan kelas literasi. Proses kegiatan pembelajaran yang berlangsung didalam kelas merupakan adanya komitmen yang dibangun oleh guru dan siswa melalui penggunaan media digital yang digunakan untuk bmeda belajar yang dimiliki oleh seorang siswa.

Guru mempunyai tugas melalui perannya dapat mengarahakn sisiwa dalam penggunaan media digital untuk keperluan belajar siswa sehingga mampu membuat siswa dapat memanfaatkan alat atau emdia digital yang dimiliki pada arah yang positif, khususnya pemanfaatannya dalam kegiatan belajar siswa di sekolah ataupun di rumah. Pemanfaatan penggunaan media digital yang dimilki siswa tentunya juga dapat dilakukan saat siswa mengikuti kelas literasi yang diadakan oleh sekolah. sehingga guru dapat lebih memaksimalkan adanya media dgitial dan kelas literasi untuk lebih membangkitakan semangat belajar siswa agar memiliki hasil belajar yang lebih baik. Tentunya Dalam kegiatan pembelajaran tersebut, guru diharapakan menyampaikan tujuan dari penggunaan media digital dan kelas literasi 
sebelum memulai proses pembelajaran. Karena melalui langkah tersebut diharapkan penggunaan media digital dan kelas literasi dapat dimaksimalkan keberadaannya oleh siswa.

Untuk itu dalam meraih hasil belajar yang berkualitas tinggi tentu tidak mudah karena pengaruh penggunaan media digital yang dibangun melalui kegiatan pembelajaran yang didukung sepenuhnya oleh kelas literasi akan mengantarkan nilai keberhasilan dalam kegiatan pembelajaran standar nasional pada setiap lembaga pendidikan.

\subsection{Pengaruh Penggunaan Media Digital}

(X1) terhadap Hasil belajar Siswa (Y)

Hasil penelitian di atas menyimpulkan bahwa penggunaan media digital telah memberikan pengaruh positif terhadap peningkatan hasil belajar siswa di SMP Anugerah Abadi di Pamulang Kota Tangerang Selatan. Hal ini mengandung arti bahwa penggunaan media digital memberikan pengaruh yang signifikan terhadap peningkatan hasil belajar siswa di SMP Anugerah Abadi di Pamulang Kota Tangerang Selatan.

Penggunaan media digital dalam hal ini adalah suatu tindakan yang dilalkukan dalam proses pembelajaran dengan tujuan untuk dapat meningkatkan hasil belajar siswa. Dikarenankan dengan penggunaan media digital ini akan mempermudah siswa dalam proses belajar. Dengan demikian berdasarkan teori-teori diatas dapat dikatakan, bahwa penggunaan media digital dalam pembelajaran dapat meningkat hasil belajar siswa.

Salah satu tugas seorang guru dan kepala sekolah adalah memberikan arahan atau petunjuk dalam penggunaan media digital dalam proses pembelajaran. Pengarahan ini sangat penting dalam setiap pembelajaran yang dilaksanakan di sebuah sekolah.

\subsection{Pengaruh Kelas Literasi (X2) terhadap Hasil Belajar Siswa (Y)}

Dari hasil penelitian dan teori yang ada dapat disimpulkan bahwa hasil belajar siswa telah memberikan pengaruh positif terhadap peningkatan hasil belajar siswa di SMP Anugerah Abadi di Pamulang Kota Tangerang Selatan. Artinya, kelas literasi yang aktif telah memberikan pengaruh positif terhadap peningkatan hasil belajar siswa di SMP Anugerah Abadi di Pamulang Kota Tangerang Selatan.

\section{SIMPULAN}

Adapun simpulan yang dapat ditarik dari hasil penelitian ini adalah sebagai berikut:

1. Terdapat pengaruh yang signifikan penggunaan media digital dan kelas literasi secara bersama-sama terhadap hasil belajar siswa. Hal ini dibuktikan dengan perolehan nilai Fo $=9,109$ dan Sig. $0,000<0,05$. Secara bersama-sama variable penggunaan media digital dan kelas literasi memberikan kontribusi 
sebesar $24,2 \%$ terhadap variable hasil belajar siswa.

2. Terdapat pengaruh yang signifikan penggunaan media digital terhadap hasil belajar siswa. Hal ini dibuktikan dengan perolehan nilai $t_{\text {hitung }}=2,214$ dan Sig. $0,031<0,05$. Variabel penggunaan media digital memberikan kontribusi sebesar $12,67 \%$ dalam meningkatkan hasil belajar siswa.

3. Terdapat pengaruh yang signifikan kelas literasi terhadap hasil belajar siswa. Hal ini dibuktikan dengan perolehan nilai $\mathrm{t}_{\text {hitung }}=2,061$ dan Sig. $0,044<0,05$. Variabel kelas literasi memberikan kontribusi sebesar $11,53 \%$ dalam meningkatkan hasil belajar siswa.

\section{DAFTAR RUJUKAN}

Wijya, Cece, dan Rusyan, A. Tabrani. (1992). Kemampuan dasar guru dalam proses belajar-mengajar. Jakarta : PT. Bumi Aksara.

Arikunto, Suharsimi. (2006). Prosedur penelitian. Jakarta : Rineka Cipta.

Syaodih, Nana. (2005). Metode penelitian pendidikan. Bandung. Program Pascasarjana Universitas Pendidikan Indonesia dengan PT Remaja Rosdakarya.

Sisdiknas. (2003). Sistem pendidikan nasional. Bandung : Penerbit Fokus Media.

Undang-Undang Republik Indonesia No. 14 Tahun 2005 tentang Guru dan Dosen., Jakarta : Eka Jaya. CV. 2006

Rahim, Farida. (2008). Pengajaran ,membaca di sekolah dasar. Jakarta : Bumi Aksara.

Widyamartay A. (1992). Seni membaca untuk studi. Yogyakarta: Kanisius 